\title{
Characteristics of Cerebrospinal Fluid in Tuberculous Meningitis Patients with Hydrocephalus
}

\author{
Astrid Tamara Maajid Budiman, ${ }^{1}$ Nida Suraya, ${ }^{2}$ Ahmad Faried, ${ }^{3}$ Ida Parwati ${ }^{2}$ \\ ${ }^{1}$ Faculty of Medicine, Universitas Padjadjaran \\ ${ }^{2}$ Department of Clinical Pathology, Faculty of Medicine, Universitas Padjadjaran-Dr. Hasan Sadikin General \\ Hospital, Bandung \\ ${ }^{3}$ Department of Neurosurgery, Faculty of Medicine, Universitas Padjadjaran-Dr. Hasan Sadikin General Hospital, \\ Bandung
}

\begin{tabular}{|c|c|}
\hline \multirow[t]{3}{*}{ Abstract } & $\begin{array}{l}\text { Objective: To describe cerebrospinal fluid (CSF) characteristics in tuberculous } \\
\text { meningitis (TBM) with hydrocephalus patients as diagnostic criteria of TBM. }\end{array}$ \\
\hline & $\begin{array}{l}\text { Methods: A cross-sectional using retrospective method was applied in this } \\
\text { study by obtaining medical records of TBM with hydrocephalus patients } \\
\text { that were treated at Department of Neurosurgery Dr. Hasan Sadikin General } \\
\text { Hospital, Bandung from January } 2014-\text { September } 2016 \text {. }\end{array}$ \\
\hline & $\begin{array}{l}\text { Results: Sixty one records were included in the study. Patient characteristics } \\
\text { such as age, gender, and CSF laboratory features such as color and clarity, cells } \\
\text { and differential count, protein, and glucose were recorded and descriptively } \\
\text { analyzed. The majority of CSF macroscopic appearance was seen to be clear } \\
(88 \%) \text { and colorless ( } 88 \% \text { ). Median for CSF cell count was } 25 \text { cells } / \mathrm{mm}^{3} \text { with } \\
\text { lymphocyte predominance (median: } 76 \% \text { ). Increased protein from normal } \\
\text { value range was seen in CSF (median: } 50 \mathrm{mg} / \mathrm{dL} \text { ) while the mean for CSF } \\
\text { glucose in this study remained in its normal value range (mean: } 58.9 \pm 26.68 \\
\mathrm{mg} / \mathrm{dL} \text { ) with lower CSF to blood glucose ratio (mean: } 0.41 \pm 0.27 \text { ). }\end{array}$ \\
\hline $\begin{array}{l}\text { Received: } \\
\text { November 2, } 2017\end{array}$ & $\begin{array}{l}\text { Conclusions: Clear CSF with colorless appearance, lymphocyte pleocytosis, } \\
\text { high protein level, and low CSF glucose as well as blood glucose ratio remain } \\
\text { typical CSF characteristics of TBM patients found at the Department of } \\
\text { Neurosurgery, Dr. Hasan Sadikin General Hospital, Bandung. }\end{array}$ \\
\hline $\begin{array}{l}\text { Revised: } \\
\text { May 15, } 2018\end{array}$ & Keywords: Cerebrospinal fluid, hydrocephalus, tuberculous meningitis \\
\hline $\begin{array}{l}\text { Accepted: } \\
\text { September 5, } 2018\end{array}$ & $\begin{array}{l}\text { pISSN: 2302-1381; eISSN: 2338-4506; http://doi.org/10.15850/ijihs.v6n2.1129 } \\
\text { IJIHS. 2018;6(2):57-62 }\end{array}$ \\
\hline
\end{tabular}

\section{Introduction}

Tuberculosis (TB) currently remains a major global health issue. Indonesia is currently in the top three in terms of TB cases where $10 \%$ of the total TB population in the world is found in this country. ${ }^{1}$ One of extrapulmonary TB with high mortality and morbidity, esepcially in children, is tuberculosis meningitis (TBM). ${ }^{2}$ Hydrocephalus is the most frequently found complication of TB and one of the predictors of mortality and morbidity. ${ }^{2}$

\footnotetext{
Correspondence:

Astrid Tamara Maajid Budiman, Faculty of Medicine, Universitas Padjadjaran

Jl. Raya Bandung-Sumedang KM 21 Jatinangor, Indonesia e-mail: astridtamaramb@gmail.com
}

Early diagnosis and proper management of TBM is an important factor that influences mortality and morbidity. Cerebrospinal fluid (CSF) examination is an important parameter in the diagnosis of TBM. This CSF examinations includes macroscopic, microscopic, chemical, and microbiological examinations. Bacterial culture or acid-fast bacilli (AFB) observation in CSF are used to establish TBM definitive diagnosis. ${ }^{2,3}$ A previous study has reported that the ratio of positive culture results were $13 \%$ among TBM patients. ${ }^{4}$ In several cases, low results of bacterial culture and AFB on CSF may be seen. Hence it is important to observe the macroscopic, microscopic, and chemical characteristic as a reference for the laboratory-based diagnosis of TBM. ${ }^{4}$ 
This study aimed to observe the chemical, macroscopic, and microscopic characteristics of CSF in TBM patients with hydrocephalus at the Department of Neurosurgery Dr. Hasan Sadikin General Hospital, Bandung.

\section{Methods}

This design used in this study was retrospective cross-sectional descriptive study. TBM patients with hydrocephalus treated at the Department of Neurosurgery, Dr. Hasan Sadikin General Hospital, Bandung who met the inclusion and exclusion criteria were included. The inclusion criteria in this study were inpatients during the period of January 2014-September 2016, with a computerized tomography (CT) scan results that suggested hydrocephalus who had undergo CSF examination with specimens derived from ventricular drainage at the Clinical Pathology Laboratory of Dr. Hasan Sadikin General Hospital, Bandung, with macroscopic, microscopic, and chemical characteristic result, including protein and glucose levels. Exclusion criteria included congenital hydrocephalus, meningitis caused by organisms other than Mycobacterium tuberculosis, positive Human Immunodeficiency Virus (HIV) status, and incomplete medical record. Samples were selected using the total sampling method.

Approval from the Ethics Committee of the Faculty of Medicine, Universitas Padjadjaran under the ethical clearance No. 102/UN6. C1.3.2/KEPK/PN/2016 was gained. This study was conducted from August to December 2016 by collecting data from the medical records of TBM inpatients with hydrocephalus i who were treated at the Department of Neurosurgery, Dr. Hasan Sadikin General Hospital, Bandung. CSF of these patients were examined at the Laboratory of Clinical Pathology of the same hospital.
Variables used in this study were age, CSF color, clarity, leukocyte cell numbers, cell count percentage, protein level, and glucose level. Data were then analyzed descriptively by counting the number and percentage for the results of macroscopic examination while for microscopic and chemical examination results, mean and standard deviations or median and range were used based on the distribution of the data.

\section{Results}

There were 477 patients with TBM in Dr. Hasan Sadikin General Hospital Bandung from 2014 to 2016 . A total of $170(35.6 \%)$ patients were treated at the Department of Neurosurgery Dr. Hasan Sadikin General Hospital, Bandung with 149 cases $(31.2 \%)$ were diagnosed as TBM with hydrocephalus. Sixty six cases (44.3) met the inclusion criteria but five of them must be excluded, resulting a total of $61(40.9 \%)$ cases. All were included in the study. All CSF samples collected from these 61 patients were taken from ventricular drainage such as extra ventricular drainage (EVD) or ventriculoperitoneal (VP) shunt.

The number of male patients was higher than the number of female patients (Table 1). Age categorization of children and adults in this study referred to the existing consensus in Dr. Hasan Sadikin General Hospital, Bandung with $0-14$ years categorized as children, and $>14$ years classified as adults. The number of pediatric patients was higher when compared to adults patients. Median age was 6 years old with a range of 6 months-58 years.

Examination of CSF was performed on TBM patients with hydrocephalus and the results were compared to normal values and criteria from Marais et al. ${ }^{3}$ (Table 2). Cerebrospinal fluid color in TBM patients with hydrocephalus

Table 1 Distribution of Tuberculous Meningitis with Hydrocephalus Patients Based on Age and Gender

\begin{tabular}{lccc}
\hline \multicolumn{1}{r}{ Gender } & Children & Adults & Total (\%) \\
\hline Male & 20 & 15 & $34(56)$ \\
Female & 19 & 7 & $27(44)$ \\
Total & 39 & 22 & $61(100)$ \\
\hline
\end{tabular}


in this study was generally colorless. Similarly, the clarity level of CSF in this study generally showed a clear result.

The median of the CSF leukocyte cells was 25 cells $/ \mathrm{mm}^{3}$ (range was $1-613$ cells $/ \mathrm{mm}^{3}$ ). The differential cell count of the cerebrospinal fluid was presented in the form of percentage of mononuclear (MN) and polymorphonuclear cells (PMN). Mononuclear cells were shown to be the dominant cell in the CSF. The scope of percentage for both PMN and MN was $0 \%$ to $100 \%$. There were two cases which showed the percentage of PMN of $100 \%$, with a CSF leukocyte cell count of $1 \mathrm{cell} / \mathrm{mm}^{3}$ in both.

The median CSF protein was higher than the normal value but not as high as the one in Marais et al. ${ }^{3}$ criteria. The mean CSF glucose was $58.9 \pm 26.68 \mathrm{mg} / \mathrm{dL}$ which was still in the normal limit. The CSF to blood glucose ratio could only be calculated in 11 patients (mean: $0.41 \pm 0.27$ ).

\section{Discussion}

This study reveals that the prevalence of TBM with hydrocephalus is predominated by males. This finding is in agreement with the results of previous studies. ${ }^{4-6} \mathrm{~A}$ study found that the prevalence of pediatric patient with TBM with hydrocephalus as complication is $71 \%$ while the same prevalence for adults is $12 \% .^{7}$ This study also shows that more children has TBM with hydrocephalus compared to adult.

Macroscopic examination on the color and clarity of CSF was performed. The macroscopic appearance of CSF in this study was generally clear and colorless. This is in line with the

Table 2 Cerebrospinal Fluid Examination in Tuberculous Meningitis Patients with Hydrocephalus

\begin{tabular}{|c|c|c|c|}
\hline Variable & Normal value & $\begin{array}{c}\text { Marais et } \text { al. }^{3} \\
\text { Criteria for TBM }\end{array}$ & Result \\
\hline \multicolumn{4}{|l|}{ Macroscopic appearance } \\
\hline CSF color* & Colorless & & \\
\hline Colorless, $\mathrm{n}(\%)$ & & & $54(88$ \\
\hline Yellowish, n(\%) & & & $4(7)$ \\
\hline Yellow, $\mathrm{n}(\%)$ & & & $3(5)$ \\
\hline Clarity & Clear & Clear & \\
\hline Clear, n(\%) & & & $54(88)$ \\
\hline Cloudy, $\mathrm{n}(\%)$ & & & $6(10)$ \\
\hline Turbid, n(\%) & & & $1(2)$ \\
\hline Microscopic examination & & & $25(1-613)$ \\
\hline CSF cells, median (range) & $<5$ cells $/ \mathrm{mm}^{3}$ & $10-500$ cells $/ \mathrm{mm}^{3}$ & cells $/ \mathrm{mm}^{3}$ \\
\hline \multicolumn{4}{|l|}{ Differential count, median (range) } \\
\hline $\operatorname{PMN}(\%)^{* *}$ & $<50 \%$ & & $24(0-100)$ \\
\hline MN (\%)\# & $>50 \%$ & $>50 \%$ & $76(0-100)$ \\
\hline \multicolumn{4}{|l|}{ Chemistry } \\
\hline Protein, median (range) & $10-40 \mathrm{mg} / \mathrm{dL}$ & $>100 \mathrm{mg} / \mathrm{dL}$ & $50(5-977) \mathrm{mg} / \mathrm{dL}$ \\
\hline $\begin{array}{l}\text { Absolute CSF glucose, mean } \pm \text { std } \\
\text { deviation }\end{array}$ & $50-80 \mathrm{mg} / \mathrm{dL}$ & $<40 \mathrm{mg} / \mathrm{dL}$ & $58.9 \pm 26.68 \mathrm{mg} / \mathrm{dL}$ \\
\hline $\begin{array}{l}\text { CSF to blood glucose ratio\#\#, } \\
\text { mean } \pm \text { std deviation }\end{array}$ & 0.6 & $<0.5$ & $0.41 \pm 0.27$ \\
\hline
\end{tabular}

Note: ${ }^{*} \mathrm{CSF}=$ Cerebrospinal fluid; ${ }^{* *} \mathrm{PMN}=$ polymorphonuclear; $\# \mathrm{MN}=$ mononuclear; \#\#Could only be done in 11 patients 
diagnosis criteria of TBM according to Marais et al. $^{3}$ Tuberculous meningitis is a chronic disease characterized by clear CSF with not really high leukocyte count and is dominated by lymphocytes. ${ }^{3,8,9}$ The inflammation response of T cell as TBM pathogenesis is demonstrated through the predominance of lymphocytes in microscopic examination of CSF, as seen in previous studies and this study. ${ }^{5,10-13}$

Marais et al. ${ }^{3}$ stated that a diagnosis criteria of chemical examination of CSF includes an increase in CSF protein $(>100 \mathrm{mg} / \mathrm{dL})$. This study shows the amount of CSF protein was not greater than $100 \mathrm{mg} / \mathrm{dL}$ as stated in the criteria diagnosis by Marais et $a l^{3}{ }^{3}$ However, the median CSF protein was in accordance with previous studies stating that the mean CSF protein was not more than $100 \mathrm{mg} / \mathrm{dL}$ despite the increase of the CSF protein value when compared to the normal value. ${ }^{6}$ As the top referral hospital in West Java, Dr. Hasan Sadikin General Hospital, Bandung, in particular the hospital's Clinical Pathology Laboratory, has their own normal CSF protein range standard of $10-40 \mathrm{mg} / \mathrm{dL}$. The CSF protein in TBM which is supposed to be increased according to the pathogenesis of TBM is considered as the result from the increased permeability of blood brain barrier or decreased reabsorption in the arachnoidalis villi., ${ }^{8,13}$

The normal value of glucose in CSF is $2 / 3$ of the plasma glucose, or approximately 50 $\mathrm{ti}=080 \mathrm{mg} / \mathrm{dL}^{8,13}$ As already explained in the criteria for TBM diagnosis, the CSF glucose should be less than $40 \mathrm{mg} / \mathrm{dL}(2.2 \mathrm{mmol} / \mathrm{L})$ or the ratio between CSF glucose and plasma glucose is lower than $50 \%{ }^{3}$ This decrease in glucose is resulted from anaerobic glycolysis caused by bacteria or disturbance in glucose transport mechanism. ${ }^{8,13}$ The mean glucose level in this study was $>40 \mathrm{mg} / \mathrm{dL}$ and wa still in the normal range of CSF glucose. This is in contrast with the diagnostic criteria by Marais et al. ${ }^{3}$ and some previous studies. ${ }^{6,9} \mathrm{~A}$ previous study presented that the number of patients with glucose level $<40 \mathrm{mg} / \mathrm{dL}$ was $48 \%$ or less than a half of all patients and that the glucose level had a wide range between $12.1-156.7 \mathrm{mg} / \mathrm{dL}$ as also shown in this study $(2-135 \mathrm{mg} / \mathrm{dL})^{11}$ There are only 11 patients whose CSF glucose to blood glucose ratio can be measured (median: $0.41 \pm 0.27$ ). This result is in line with the diagnostic criteria by Marais et al. ${ }^{3}$ which stated that CSF glucose to blood glucose ratio is $<50 \%$.

Most previous studies that have discussed the CSF characteristics in TBM use CSF to blood glucose ratio $<0.5$ as one ofdiagnostic criteria for TBM. ${ }^{4,14}$ The previous studies showed that the sensivity of the low absolute CSF glucose was low, that is $68 \%$ and $69,5 \%{ }^{12,15}$ On the other hand, previous studies also showed that the sensitivity of low CSF to blood glucose ratio was $90 \% .{ }^{15}$ This explains why the normal absolute CSF glucose level cannot rule out the possibility of infection and it had also been suggested that considerations should be given to use CSF to blood glucose ratio as additional information for diagnosis of TBM. ${ }^{15}$

The difference of CSF content in this study compared to Marais et al. ${ }^{3}$ criteria might be caused by the CSF source itself. ${ }^{16}$ Previous study had shown difference CSF composition between ventricular and spinal CSF that may be caused by the disease's pathophysiology. ${ }^{16}$ The impaired blood-brain barrier leads to a higher protein composition which may slow down the circulation of CSF and may impair CSF absorption or obstruct the CSF pathway that causes hydrocephalus after aggregation of CSF protein and leukocytes caudally. ${ }^{16}$

The median of age in this study (median: 6 years) reflects a higher distribution among children below 6 years old. Several previous studies have shown age-related variations in CSF protein content. ${ }^{8,17}$ It is shown here that there is a lower protein CSF value in children when compared to adults and this might result in lower protein CSF in this study compared to the Marais et al. ${ }^{3}$ criteria. ${ }^{8,17}$

Furthermore, the use of antimicrobial agent before ventricular drainage may also affect CSF protein and glucose content. ${ }^{18}$ Time of interval median between the occurence of tuberculosis to hydrocephalus development was 21 days (range: 3-180 days). In between, patients consumed antituberculous drugs. A previous study has shown that CSF glucose will increase and CSF protein will decrease significantly after the use of antibiotic, especially in the period of $>12$ hours postantibiotics. ${ }^{18}$

There are several limitations in the study including the small sample size, i.e. 61 samples. This is due to the limited time and rejection from some TBM patients with hydrocephalus to undergo ventricular drainage that includes both EVD and VP shunts. In addition, incomplete patient records and archives creates another limitation, especially when the result of CSF in patient who underwent ventricular drainage is missing. Another reason is that blood glucose measurement done 15-30 minutes prior to the ventricular drainage was not done in almost all samples. This makes the calculation of CSF to glucose ratio cannot be performed in almost all patients. Specimen was also taken from 
ventricular drainage that may also affect the results compared to those of previous studies that mostly used lumbar fluid as specimens.

In conclusion, the diagnosis of tuberculous meningitis is still problematic, especially with the high number of the hydrocephalus seen. CSF presentations such as clear and colorless CSF, lymphocyte pleocytosis, increased protein level, and lower CSF to blood glucose ratio

\section{References}

1. World Health Organization. Global tuberculosis report 2015. 20 $0^{\text {th }}$ ed. Geneva: World Health Organization, 2015.

2. Rock RB, Olin M, Baker CA, Molitor TW, Peterson PK. Central nervous system tuberculosis: pathogenesis and clinical aspects. Clin Microbiol Rev. 2008;21(2):243-61.

3. Marais S, Thwaites G, Schoeman JF, Torok ME, Misra UK, Prasad K, et al. Tuberculous meningitis: a uniform case definition for use in clinical research. Lancet Infect Dis. 2010;10(11):803-12.

4. Güneș A, Uluca Ü, Aktar F, Konca Ç, Şen V, Ece $A$, et al. Clinical, radiological and laboratory findings in 185 children with tuberculous meningitis at a single centre and relationship with the stage of the disease. Ital J Pediatr [serial on the internet]. 2015 Oct [cited 2017 Aug 12];41(75):[about 6p.]. Available from: https://www.ncbi.nlm.nih.gov/pmc/articles/ PMC4606503/.

5. Pinto VL, Lima MA, Rolla VC, Rebelo MC, Boia MN. Atypical cerebrospinal fluid profile in tuberculous meningitis. Trop Doct. 2009;39(2):76-8.

6. Shaikh MA, Shah M, Channa F. Criteria indicating morbidity in tuberculous meningitis. J Pak Med Assoc. 2012;62(11):1137-9.

7. Rajshekhar V. Management of hydrocephalus in patients with tuberculous meningitis. Neurol India. 2009;57(4):368-74.

8. Karcher DS, McPherson RA. Cerebrospinal, synovial, serous body fluids, and alternative specimens. In: McPherson RA, Pincus MR, editors. Henry's clinical diagnosis and management by laboratory methods. $22^{\text {nd }} \mathrm{ed}$. Philadelphia: Elsevier Saunders; 2011. p. 48092.

9. Qamar FN, Rahman AJ, Iqbal S, Humayun K. Comparison of clinical and CSF profiles in children with tuberculous and pyogenic are still the typical characteristics found in TBM with hydrocephalus in Dr. Hasan Sadikin General Hospital, Bandung. Examination of CSF in TBM may be done in every level of health facilities as it is the easiest way to diagnose this disease. This study suggests the use of CSF to blood glucose ratio as a routine examination to in TBM diagnosis.

meningitis; role of CSF protein: glucose ratio as diagnostic marker of tuberculous meningitis. J Pak Med Assoc. 2013;63(2):206-10.

10. Salekeen S, Mahmood K, Naqvi IH, Baig MY, Akhter ST, Abbasi A. Clinical course, complications and predictors of mortality in patients with tuberculous meningitis-an experience of fifty two cases at Civil Hospital Karachi, Pakistan. J Pak Med Assoc. 2013;63(5):563-7.

11. Christensen A-SH, Andersen ÅB, Thomsen VØ, Andersen PH, Johansen IS. Tuberculous meningitis in Denmark: a review of 50 cases. BMC Infect Dis. 2011;11(1):1-6.

12. Solari L, Soto A, Agapito JC, Acurio V, Vargas D, Battaglioli $\mathrm{T}$, et al. The validity of cerebrospinal fluid parameters for the diagnosis of tuberculous meningitis. Int J Infect Dis [serial on the internet]. 2013 Dec [cited 2016 Nov 18];17(12):[about 5p.]. Available from:https://www.ijidonline.com/article/ S1201-9712(13)00214-2/fulltext.

13. Cerebrospinal fluid. In: Strasinger SK, Di Lorenzo MS, editors. Urinalysis and body fluids. $6^{\text {th }}$ ed. Philadelphia: F.A. Davis Company; 2008. p.177-95.

14. Thwaites G, Fisher M, Hemingway C, Scott G, Solomon T, Innes J. British Infection Society guidelines for the diagnosis and treatment of tuberculosis of the central nervous system in adults and children. J Infect. 2009;59(3):16787.

15. Solomons RS, Visser DH, Donald PR, Marais BJ, Schoeman JF, van Furth AM. The diagnostic value of cerebrospinal fluid chemistry results in childhood tuberculous meningitis. Childs Nerv Syst. 2015;31(8):1335-40.

16. Alfayate-Miguelez S, Martinez-Lage-Azorin L, Marin-Vives L, Garcia-Martinez S, Almagro MJ, Martinez-Lage JF. Normal ventricular-CSF may comfound the diagnosis of tuberculous 
meningitis hydrocephalus. Neurocirugia (Astur). 2011;22(2):157-61.

17. Miftode EG, Dorneanu OS, Leca DA, Juganariu G, Teodor A, Hurmuzache M, et al. Tuberculous meningitis in children and adults: a 10-year retrospective comparative analysis. PLoS One. 2015 Jul [cited 2016 Nov 18];10(7):[about 10p.] Available from: http://journals.plos. org/plosone/article/file?id=10.1371/journal. pone.0133477\&type=printable.

18. Nigrovic LE, Malley R, Macias CG, Kanegaye JT, Moro-Sutherland DM, Schremmer RD, et al. Effect of antibiotic pretreatment on cerebrospinal fluid profiles of children with bacterial meningitis. Pediatr. 2008;122(4):72630. 